\title{
IMPLEMENTATION OF PROBLEM CREDIT DEBTACCORDING TO CIVIL LAW
}

\author{
Ashar Sinilele \\ Alauddin State Islamic University Makassar \\ Email : asharsin769@gmail.com
}

\begin{abstract}
The policy of implementing haircuts at the Bank has accelerated the restructuring of small and medium business loans. The issuance of these two decrees and the imposition of haircuts in theworld bankingfor certain parties have caused a legal problem, namely a decree has set aside all the rules stipulated in the existing laws, for example the rules regarding contract law. in the Civil Code. This is a deviation from the applicable legal principle, namely that higher regulations override lower regulations. Based on experience to achieve the expected effectiveness, it is better if thepolicy haircut through a presidential decree does not only provide discounts on bad loans but also does not limit the time interval for the loss, the important thing is that the debtor's criteria meet the requirements of SMEs affected by the monetary crisis.
\end{abstract}

\section{Keywords: Debt Cutting, Credit, Civil Law}

\section{INTRODUCTION}

Banking is part of the monetary system which if disturbed will greatly affect the life of the national economy. The monetary crisis that began to be felt in mid-1997, when the Asian region was hit by another crisis, contributed to the destruction of the dollar exchange rate in Indonesia. As a result of the depreciating value of the rupiah, it caused a monetary crisis in Indonesia which devastated the foundations of the economy, including banking.

As a result of the depressed rupiah value causing a monetary crisis in Indonesia, which shattered the foundations of the economy, including banking, when the monetary/economic crisis hit Indonesia in 1998, non-performing loans (NPLs) experienced a remarkable increase in a number of banks, then- encourage the stagnation of economic development marked by high inflation. This condition is the trigger for the decline in national banking so that the number of NPLs has reached a tip. 264.8 trillion where this figure penetrated almost $50 \%$ of the total value of loans disbursed in $1998 .{ }^{1}$

As a result of the warming economy, in 1991 the government adopted a policy known as the "Tight Money Policy" or tight money policy to prevent expansion in the

${ }^{1}$ Sutarno, 2004, Aspek-aspek Hukum Perkreditan pada Bank, Alfabeta, Bandung. Hal. 253.

Jurisprudentie | Volume 8 Nomor 2 Desember 2021 
financial sector which was out of control. Therefore, the government adopted the policy of deregulation of the February Package (Pakfeb) 1991, but this policy, known as the "Sumarlin breakthrough", was unable to overcome the credit expansion that had already penetrated the national banking sector. The credit expansion carried out by the banking sector, both by national private banks and state banks, continued until its peak in mid1997, until the end of the crisis that hit the foundations of our national economy. In order to save the Indonesian banking world as a whole, the government has taken various policy steps, namely structuring banks such as: liquidating 16 national private banks, freezing the operations of banks that still have future prospects. Apart from the collapse of the banking world from the impact of the crisis, the real sector business world, generally also experienced bankruptcy shocks that were almost unimaginable before, causing credit that had been given by banks to become problematic because of their inability to repay loans according to the schedule agreed in the credit agreement and other accecoir agreements. ${ }^{2}$

Problem loans really can't separated from the banking world, but if seen from the increase sufficient. On the other hand, since our country was hit by a monetary and economic crisis, this should not be allowed or considered as just a routine work in terms of its completion as before the crisis occurred, but more extra and extraordinary solutions need to be taken. ${ }^{3}$

Referring to the basis of the relationship between the bank and the customer, (the debtor) where the legal umbrella should be used if the credit becomes problematic and negotiations between the parties are no longer possible, again are agreements that bind both parties. The agreement can be in the form of a Credit Agreement, Mortgage Agreement, Agreement. Fiduciary or in the form of existing laws and regulations. ${ }^{4}$

In addition to the policies carried out by the bank's internal parties, it also appears that there are policy interventions from the government in the context of resolving nonperforming loans, seeing that the above conducive situation and conditions require that unconventional policy methods be adopted. ${ }^{5}$

${ }^{2}$ Lamar Basalim et al., 2000 . Perekonoiniatz Indonesia, crisis and Alternative Strategies, UNAS, Jakarta. Hal. 34.

${ }^{3}$ Idris, Miftah. "Kerahasiaan Bank Suatu Tinjauan Dalam Aturan Hukum Perbankan Syariah Di Indoesia." Al-Amwal: Journal of Islamic Economic Law, Volume 1, Nomor, 1, (2016), Hal .21.

${ }^{4}$ Wafa, Moh Ali. "Hukum perbankan dalam sistem operasional bank Konvensional dan bank syariah." Kordinat: Jurnal Komunikasi antar Perguruan Tinggi Agama Islam, Volume 16, Nomor. 2 (2017), hal. 260.

${ }^{5}$ Hidayati, Maslihati Nur. "Dewan pengawas syariah dalam sistem hukum perbankan: Studi tentang pengawasan bank berlandaskan pada prinsip-prinsip Islam." Lex Jurnalicam, Volume 6, Nomor 1, (2008), Hal 18055. 


\section{RESEARCH METHODS}

This research was conducted in Makassar City, especially in several banks in Makassar. This study seeks to collect as much as possible two types of data from different data sources, namely Primary Data or empirical data that has practical value, because it comes from the knowledge and experience of respondents obtained directly and Secondary Data or theoretical data, because it comes from material. readings or literature and documentation, including case files that have been experienced by many banks so far. Primary data and secondary data that have been collected during the course of the research will be arranged systematically according to type, type and source. Then the data was analyzed qualitatively.

\section{RESULTS AND DISCUSSION}

\section{A. Implementation of Debt Cutting Policy Share Credit Troubled.}

The banking world is the sector that has felt the most from the crisis that occurred in early 1997 and also today. The prolonged economic crisis createdmultiplier effect a negativein all sectors, while in other crises, the rupiah exchange rate continued to be depressed by the US Dollar exchange rate to its lowest point. The crisis in Indonesia began with the depreciation of the rupiah exchange rate, which later became a monetary crisis and after that it expanded and developed into a total crisis involving almost all aspects of life in society. ${ }^{6}$

The weakness of Indonesia's financial structure has caused a crisis that has spread from the economic monetary crisis to all aspects of people's lives. Due to the weakness of the economic structure, social order, law and politics, this problem has become a systematic problem. The banking crisis that occurred in Indonesia closely related to the macro-economic system, government policy, legal, political, and so forth. ${ }^{7}$

The banks that carried out their business activities after the recapitalization had insufficient profits compared to their overall operating costs. The gain shown in the income statement due to the interest expense on recapitalization bonds has resulted in the interest expense being borne by the state as long as the recapitalization bonds held at the banks are not withdrawn. ${ }^{8}$

Recapitalization bonds can be withdrawn or reduced at The assets held at IBRA at that time were successfully sold at a good price and then exchanged for bonds, but because the state itself was experiencing budget constraints, the sale of assets held at

\footnotetext{
Hal. 76.

${ }^{6}$ Risna Wijaya, 2000. Analysis of the National Banking Crisis, Kompas Media Nusantara, Jakarta.

${ }^{7}$ Mudrajad Kuncoro and Suharcijono, 2002. Application Banking Management, BPFE Gajah Mada University, Yogyakarta. Hal .126.

${ }^{8}$ Munir Fuady, 2002. Introduction to Business Law, Citra Aditya Bakti, Bandung. Hal. 34.
} 
IBRA at that time was not used for withdrawals. The recapitalization bonds in the recapitalization banks, but the sales proceeds are mostly used to cover the budget shortfall.

The government's response to the very bad banking condition was to provide apolicy haircut for problem loans based on the government's policy, because the source of the recapitalization funds came from government bonds, while the banks themselves directly benefited from bond interest which became the burden of the government, which in turn became the burden of the people. ${ }^{9}$

The rescue of non-performing loans in banking was caused by political factors, the reason being that this policy was adopted because of the intervention from the government to Indonesian banks so that in resolving non-performing loans due to the monetary crisis it could be resolved wisely. ${ }^{10}$

Settlement by negotiation is an effort made by the bank with the aim of rescuing, credit, and credit withdrawals and terminating the relationship with credit rescue at Bank Danamon is an attempt by the bank to prevent the possibility of further losses arising on a credit which is in cliusal attention, substandard, doubtful or even stalled through managing customer relationships. ${ }^{11}$

The form of rescue loans at the Bank are as follows:

1. Rescheduling (Rescheduling)

Rescheduling is a change in the terms - which concerns only the credit terms and payment schedule or the time period, including a grace period if there is or not a change in the amount of the installment.

2. Terms of Return (Reconditioning)

back requirements are partially or completely change credit terms are not limited to changes in payment schedules, duration and or other requirements as far as not relating to changes in the maximum credit balance.

3. Structuring Back (Restructuring)

Deed Pemb $b_{1}$ Erian Mortgage and Certificates of Mortgage serves as Grosse Deed with basic hukuimiya is Article 14 paragraph (3) of the Act Mortgage, which contains iRate-iRate "By Justice Perdasa.), Belief in God One". Certificates, Mortgage has the same executorial power of the court verdict has obtained permanent legal force.,

\footnotetext{
${ }^{9}$ Soedradjad Djiwandono, 2001. Grappling with Indonesia's Economic Crisis and Recovery, Sinar Harapan Library, Jakarta. Hal .56

10 Kwik Kian Gie, 1998. Analysis of the National Banking Crisis, Kompas Media Pustaka Utama and IBII School of Economics, Jakarta. Hal. 98.

11 Cipto Darmaji, 2001. Restructuring (Mentullhkan and Accelerate National Economic WIDLGramedia, asarana Jakarta. Hal. 45
} 


\section{B. Effects of Implementation Haircut NPL.}

Based on the results of the author's research at Bank Danamon Makassar Branch, it describes that thepolicy haircut has 2 (two) implications, namely non-legal implications and legal implications.

The non-legal implications in the government's policy-making process were greatly influenced by the political situation and stability at that time. Contract law adheres to an open system, which contains the principle of freedom to make agreements (commonly known as the principle of freedom to contract or Freedom to Contract, (Contractz) rijheid). This principle in the Civil Code which is concluded in Article 1338 paragraph (1), namely: All agreements. What is legally made applies as law to those who make it.

Article 1338 paragraph (1) also concludes the existence of theprinciple Pacta Sunt Servanda which means that an agreement is made to be obeyed by the parties who make it. According to legal science, especially agreements, there are many things that if done by the debtor, the debtor will be considered to be in a state of default (default).

Several circumstances can lead the debtor into a state of negligence or default, including: ${ }^{12}$

\section{Payment Default The}

Debtor in this case is considered negligent if the debtor is unable to repay the loan principal or interest, when the loan is due, or does not make payments other costs which are its obligations under the credit agreement or other related documents.

2. Default related to Representations

Representations and warranties are part of an agreement which implies guarantees from the debtor of the truth and validity of the company's actions as well as from the existing documents. In the event that any of these matters later turns out to be incorrect or invalid, then the debtor is deemed to have defaulted. ${ }^{13}$

3. Default related to prohibited matters (Covenant Defaitit)

Actions or changes in violation of things that cannot be done by the debtor as specified in. agreement (negative covenant) can bring the debtor into a state of default. Prohibitions (negative covenants) may include: a ban on mergers, acquisitions, consolidations and the sale of assets, a ban on taking credit others, a ban on taking dividends, a ban on the changes that are corporate changes, a ban on transactions except ordinary transactions a day -normal day (Ann's length

\footnotetext{
${ }^{12}$ Single Imam Syaputra, 1999. Banking Regulation Legislation in Indonesia

from 1997 to 1998, Book III, Harvarindo, Jakarta. Hal. 97.

${ }^{13}$ Umam, K. Pelarangan Riba dan Penerapan Prinsip Syariah dalam Sistem Hukum Perbankan di Indonesia. Mimbar Hukum-Fakultas Hukum Universitas Gadjah Mada, Volume 29, Nomor (3, (2017).Hal. 392.
} 
transaction), no changeover. management or shareholders and others. ${ }^{14}$

4. Default on other obligations The

Debtor's failure to comply with other articles in the credit agreement other than the prohibition clauses or the articles concerning representation and warranties, ${ }^{15}$ can also bring the debtor into a state of default. Default against these other articles is usually effective if after a certain period of time (eg 14 days) has passed after a warning has been issued by the creditor, but the debtor does not make corrections for his mistakes. ${ }^{16}$

5. Default due to Licensing (Approval Default)

Default arising from cancellation of, approval, ratification, or power of attorney by the competent authority, or not obtaining permits, approval, ratification or power of attorney from the competent authority, even though in the credit agreement this is required .

\section{Cross Default (Cross Default)}

In the credit agreement system if there is more than one creditor, then all creditors are considered legally as one entity. Likewise, if there are several parties who are obliged to bear the debt other than the debtor. For example, in addition to the debtor, there are parties who must provide subordinated loans in certain cases.

According to the principle of cross default, if all or one of those who are obligated to default to all or one of the creditors, then the debtor is considered a defaulter, so that the party who also guarantees the debtor's debt base who has not made a mistake must share the burden.

7. Default due to a fundamental change (Adverse Change Default)

If according to the creditor's consideration there has been a fundamental change that will adversely affect the debtor's ability to pay its debts, the debtor can be declared in default. Such fundamental changes include but are not limited to political, social or economic upheaval, or even changes in the debtor's business or other actions taken by the government, such as confiscation, or release of debtor assets by the government, or termination of its management.

8. Default due to Legal Cases (Judgment Default)default

This involves a company, management/ commissioner, shareholder or individual involved in civil or criminal cases which, according to creditors' considerations, can have a significant impact (adversely affect) on debt payments,

14 Whim Muhammad, 2000. Banking Law in Indonesia, (Development, Prospects and Management), Citra Aditya Bhakti, Bandung. Hal. 76.

${ }^{15}$ Mansyur, M. Ali. "Aspek Hukum Perbankan Syariah dan Implementasinya di Indonesia." Jurnal Dinamika Hukum, Volume 11, Nomor 1, (2011), Hal. 75

16 Zanuddin Rahman, 1998. Legal Aspects of Banking Lending in Indonesia, Citra Aditya Bhakti, Bandung. Hal. 243. 
debtors or in carrying out their daily business.

\section{Default due to Bankruptcy (Bankruptcy Default) The}

Declaration of bankruptcy by the Commercial Court against an individual or legal entity results in the debtor being in a state of default.

10. Default due to negligence on other agreements

Debtors who have engagements with other creditors and defaulting, resulting in the creditor considering that if the debtor's default with other creditors will adversely affect the debtor's ability to pay, the creditor may declare the debtor in default.

Default due to delays in the implementation of the agreement (Completion Date Default) Credit agreements usually determine when an achievement by one or both parties is completed, for example, if a credit is given for work a project, then until a certain date (completion date) the project has not been completed, then the debtor is considered a default. ${ }^{17}$

\section{CONCLUSION}

The policy haircut at the Bank has accelerated the restructuring of small and medium business loans, where by allowing banks to provide discounts on principal debts. The legal consequence of implementing haircuts for bad loans is apolicy haircut based on a decree. Policy Committee, Financial Sector and Presidential Decision. The issuance of these two decrees and the imposition of haircuts in theworld bankingfor certain parties have caused a legal problem, namely a decree has set aside all the rules stipulated in the existing laws, for example the rules regarding contract law. in the Civil Code. This is a deviation from the applicable legal principle, namely that higher regulations override lower regulations.

\section{REFERENCE}

\section{Journal}

Hidayati, Maslihati Nur. "Dewan pengawas syariah dalam sistem hukum perbankan: Studi tentang pengawasan bank berlandaskan pada prinsip-prinsip Islam." Lex Jurnalicam, Volume 6, Nomor 1, (2008).

17 Hadiwidjaja. H. clan RA Rivai Wirasasmita, 1993. Several aspects of credit management, Pioneer Jaya, Bandung. Hal. 231. 
Idris, Miftah. "Kerahasiaan Bank Suatu Tinjauan Dalam Aturan Hukum Perbankan Syariah Di Indoesia." Al-Amwal: Journal of Islamic Economic Law, Volume 1, Nomor, $1,(2016)$.

Mansyur, M. Ali. "Aspek Hukum Perbankan Syariah dan Implementasinya di Indonesia." Jurnal Dinamika Hukum, Volume 11, Nomor 1, (2011). Umam, K. Pelarangan Riba dan Penerapan Prinsip Syariah dalam Sistem Hukum Perbankan di Indonesia. Mimbar Hukum-Fakultas Hukum Universitas Gadjah Mada, Volume 29, Nomor (3, (2017).

Umam, K. Pelarangan Riba dan Penerapan Prinsip Syariah dalam Sistem Hukum Perbankan di Indonesia. Mimbar Hukum-Fakultas Hukum Universitas Gadjah Mada, Volume 29, Nomor (3, (2017).

Wafa, Moh Ali. "Hukum perbankan dalam sistem operasional bank Konvensional dan bank syariah." Kordinat: Jurnal Komunikasi antar Perguruan Tinggi Agama Islam, Volume 16, Nomor. 2 (2017).

\section{Books}

Whim Muhammad, 2000. Banking Law in Indonesia, (Development, Prospects and Management), Citra Aditya Bhakti, Bandung.

Zanuddin Rahman, 1998. Legal Aspects of Banking Lending in Indonesia, Citra Aditya Bhakti, Bandung.

Hadiwidjaja. H. clan RA Rivai Wirasasmita, 1993. Several aspects of credit management, Pioneer Jaya, Bandung.

Asmir, 2001. Banks and Other Financial Institutions, PT. Raja Grafindo Persada, Jakarta.

Risna Wijaya, 2000. Analysis of the National Banking Crisis, Kompas Media Nusantara, Jakarta.

Kwik Kian Gie, 1998. Analysis of the National Banking Crisis, Kompas Media Pustaka Utama and IBII School of Economics, Jakarta.

Dendawijaya, 2001. Banking Management, Ghalia Indonesia, Jakarta.

Mudrajad Kuncoro and Suharcijono, 2002. Application Banking Management, 
BPFE Gajah Mada University, Yogyakarta.

Munir Fuady, 2002. Introduction to Business Law, Citra Aditya Bakti, Bandung.

Rachmat Firdaus and Maya Ariyanti, 2004. Commercial Bank Credit Management (Theory, Problems, Policies and Applications Complete with Credit Analysis), Alfabeta, Bandung.

Soedradjad Djiwandono, 2001. Grappling with Indonesia's Economic Crisis and Recovery, Sinar Harapan Library, Jakarta.

Sutarno, 2004. Legal Aspects of Credit in Banks, Alfabeta, Bandung.

Cipto Darmaji, 2001. Restructuring (Mentullhkan and Accelerate National Economic WIDLGramedia, asarana Jakarta.

Single Imam Syaputra, 1999. Banking Regulation Legislation in Indonesia from 1997 to 1998, Book III, Harvarindo, Jakarta.

Lamar Basalim et al., 2000 . Perekonoiniatz Indonesia, crisis and Alternative Strategies, UNAS, Jakarta.

\section{Regulations and Act}

Law Number 10 Year 1998 on Banking,

Financial Sector Policy Committee No. KEP.01 / K.KKSK / 01/2001 On 16th January 2001

PEPRES No. 56 of 2002 concerningPolicy Haircut Non-performing Credit on Banks. 